\title{
HUMAN RESOURCES MANAGEMENT STRATEGY AND PERFORMANCE OF NATIONAL INDEPENDENT POWER PROJECTS
}

\author{
Onwuama, Emeka Michael, Ph.D \\ Humanities Unit, School of General Studies \\ University of Nigeria, Enugu Campus \\ Email: emeka.onwuama@unn.edu.ng \\ Obiora, Anichebe, Ph.D. \\ Department of Philosophy, University of Nigeria, Enugu Campus
}

Abstract
The study was to evaluate human resources management strategy and performance of National Independent Power Project. The specific objectives were to: examine the relationship between training and development on the profitability of National Independent Power Project, evaluate the relationship between recruitment and selection on the input of National Independent Power Project and determine the relationship between health and safety on the staff retention of National Independent Power Project. Study of Enugu Distribution Company, South East, Nigeria, comprising of Abia, Ebonyi, Enugu, Anambra and Imo states. They study covered period of (2008-2020). The study used the survey approach. The administration of questionnaire was done to the management and staff of the Enugu distribution Company Out of a population of 8.556 staff, the sample size of 364 was chosen after applying the Freund and William's formula for the determination of adequate sample size. 336 staff returned the questionnaire and accurately filled. That gave 92 percent response rate. Pearson correlation coefficient, (F-statistics), and regression analysis were used to test the hypotheses, determine the nature, and strength of the research variables. The findings indicated that there was a relationship between training and development on the profitability of National Independent Power Project with two-tailed test $r(95, n=336)=.71, p<.05)$, recruitment and selection had a relationship with the input in National Independent Power Project with two-tailed test $\mathrm{r}(95, \mathrm{n}=336)=.67, \mathrm{p}<.05)$ and there was a relationship between health and safety on the staff retention of National Independent Power Project with two-tailed test $\mathrm{r}(95, \mathrm{n}=336)=.67, \mathrm{p}<.05)$. The study concluded that there is a relationship between training and development, recruitment and selection, health and safety on the profitability, input and staff retention of National Independent Power Project. The study recommended that manufacturing employees should be put through mandatory induction courses that predominantly focus on health and safety in National Independent Power project.

Keywords: Human Resource Management Strategy, Recruitment, Selection, Health and Safety, Input,StaffRetention.

\subsection{Introduction}

Human resource management is concerned with the development of both individuals and the organization in which they operate. HRM, then, is engaged not only in securing and developing the talents of individual workers, but also in implementing programs that enhance communication and cooperation between those individual workers in order to nurture organizational development. The primary responsibilities associated with human resource 
management include: job analysis and staffing, organization and utilization of work force, measurement and appraisal of work force performance, implementation of reward systems for employees, professional development of workers, and maintenance of work force. Human resource management is a key part of keeping a business alive and successful. Every business involves people, and making sure those people are doing their best work is what keeps the company moving forward (Smyth, 2019).

Human resource management strategies are the plans that lead to implementing different functions in the human resources department of an organization. The different functions that c (Seidel, 2019). Human resource management strategy is a designation for a long-term plan created to achieve objectives in the field of human resource and human capital management and development in the organization. Human Resource strategy is one of the outputs of strategic management in the field of human resources management. The Human Resource management strategy sets the direction for all the key areas of HR, including hiring, performance appraisal, development, and compensation (Erik, 2019).

Compliance with laws and regulation, management changes, leadership development, workforce training and development, adapting to innovation, compensation, understanding benefits packages, recruiting talented employees, retaining talented employees and workplace diversity are the common human resource management challenges. Strategic human resource management is an approach to the practice of human resources that addresses business challenges and makes a direct contribution to long-term objectives. The primary principle of strategic human resource management is to improve business performance and uphold a culture that inspires innovation and works unremittingly to gain a competitive advantage. It is a step above traditional human resources and has a wider reach throughout the organization (Mitchell, 2020).

\subsection{Statement of the Problem}

Human resource management strategy helps to implement structure and job design, employee recruitment and selection, employee training and development, compensation and benefits, performance management, employee and labour relations, policy formation, these are key functions that can be managed in a number of different ways depending on resources, strategy and priority.

Human resource management common challenges are inadequate compliance with laws and regulation, management changes, leadership development, workforce training and development, adapting to innovation, compensation, understanding benefits packages, recruiting talented employees, retaining talented employees and workplace diversity .

Most manufacturing firms are faced with the above problems resulting to poor profitability, inadequate and low quality input, poor motivation of workers and inability of staff retention. The above necessitate the need to evaluate human resources management strategy and performance of National Independent Power Project.

\subsection{Objective of the Study}

The main objective of the study was to evaluate human resources management strategy and performance of National Independent Power Project. The specific objectives were to:

i. Examine the relationship between training and development on the profitability of National Independent Power Project

ii. Evaluate the relationship between recruitment and selection on the input of National Independent Power Project.

iii. Determine the relationship between health and safety on the staff retention of National Independent Power Project. 


\subsection{Research Questions}

The following research questions guided the study

i. What is the relationship between training and development on the profitability of National Independent Power Project?

ii. What is the relationship between recruitment and selection on the input of National Independent Power Project?

iii. What is the relationship between health and safety on the staff retention of National Independent Power Project?

\subsection{Statement of Hypotheses}

The following alternate hypotheses guided the study

i. There is a relationship between training and development on the profitability of National Independent Power Project

ii. Recruitment and selection has relationship with the input in National Independent Power Project

iii. There is a relationship between health and safety on the staff retention of National Independent Power Project.

\subsection{Significance of the Study}

The study will be of great help to government in implementing policies that will facilitate manufacturing firms' productivity and performance. The study will be of benefit to the students since it will enable them in acquiring knowledge on human resource management strategy. Manufacturing firms will benefit irrespective of how proper their programmes are articulated have to take cognizance of human resource management strategies to improve their performance and actualize their stated goals.

\subsection{REVIEW OF RELATED LITERATURE \\ 2.1 Conceptual Framework}

\subsubsection{Human Resource Management}

Human resource management is concerned with the development of both individuals and the organization in which they operate. It is engaged not only in securing and developing the talents of individual workers, but also in implementing programs that enhance communication and cooperation between those individual workers in order to nurture organizational development. The primary responsibilities associated with human resource management include: job analysis and staffing, organization and utilization of work force, measurement and appraisal of work force performance, implementation of reward systems for employees, professional development of workers, and maintenance of work force (Canal, 2020). The HRM department members provide the knowledge, necessary tools, training, administrative services, coaching, legal and management advice, and talent management oversight that the rest of the organization needs for successful operation. Many HR departments are responsible for organization development that generates the culture of the organization. They are charged with oversight responsibilities to ensure that their organization appropriately builds teams and inspires employee empowerment (Heathfield, 2019).

\subsubsection{Strategies}

Strategy is an action that managers take to attain one or more of the organization's goals. Strategy can also be defined as "A general direction set for the company and its various components to achieve a desired state in the future. Strategy results from the detailed 
strategic planning process.A strategy is all about integrating organizational activities and utilizing and allocating the scarce resources within the organizational environment so as to meet the present objectives. While planning a strategy it is essential to consider that decisions are not taken in a vacuum and that any act taken by a firm is likely to be met by a reaction from those affected, competitors, customers, employees or suppliers (Juneja, 2015). The importance of strategy is manifold but the most important aspect is competitive advantage. Because of marketing strategy, firms are able to stay ahead of theircompetitors or at least able to beat the competitors who are below them in market standing. With good strategy, firms might beat the top competitor as well. Having a clear and focused strategy is critically important to the success of any business, and without a well-defined strategy, it may stall or even fail (Chirgwin, 2016).

\subsubsection{Human Resource Management Strategies}

Human resource management strategies are the plans that lead to implementing different functions in the human resources department of an organization. Every business no matter how small needs a way to deal with hiring, employee development, conflict resolution and compensation, HRM strategies do not need to be overwhelmingly complex for every business. A company with few employees and an overall strategy of sustaining business rather than aggressive growth will be fine with a very simple HR strategic approach (Smyth, 2019). Companies are more likely to be successful when all teams are working towards the same objectives. Strategic HR carries out analysis of employees and determines the actions required to increase their value to the company. The implementation of strategic human resource management entails developing a thorough understanding of the company's objectives, evaluating of human resource capability, analyzing the current human resource capacity in light of the organizational goals, estimating the company's future human resource requirements, determining the tools required for employees to complete the job, implementing the human resource management strategy and periodic evaluation and collective action (Sawyer, 2019).

\subsubsection{Performance}

Organizational performance means the actual output or results of an organization as measured against its intended outputs (or goals and objectives). Performance' is defined to include "the action or process of performing a task or function seen in terms of how successfully it is performed". Organisation performance relates to how successfully an organised group of people with a particular purpose perform a function. High organisational performance is when all the parts of an organisation work together to achieve great results with results being measured in terms of the value we deliver to customers (Louise, 2012). The performance management process combines information gathering through monitoring goal completion, feedback and discussions. By analysing successes, strengths, learning from mistakes and examining potential for growth and development, businesses can develop talent, enhance individual performance and weed out problems. An effective performance management system requires commitment and dedication from the human resources department and managers and employees (Stuart, 2018).

\subsubsection{National Independent Power Project}

Nigerian National Integrated Power Project NIPP) was conceived in 2004 during the administration of President OlusegunObasanjo, with the aim to address the issues of insufficient electric power generation and excessive gas flaring from oil exploration in the Niger Delta region, in that effect seven power plants were designed in gas-producing states as part of the project. The outputs of the power plants after their inception were presented with 
respect to the existing Nigerian grid network. It was found that the power plants account for about $25 \%$ of the total electricity generated. It was also established that because of the shortage of gas supply, the NIPP power plants accounted for about 54\% of the total constrained electricity generation. The proposed power projects failed to achieve their objectives due to mainly gas pipeline destruction in the region (Okedu, 2018).

\subsubsection{Recruitment and Selection}

Recruitment and selection is one of the important aspects of human resource planning. Human resource planning ensures that right kind and right quality of employees are employed so as to achieve the organizational goals. The process of searching suitable candidates and attracting them to apply for the vacancies in the organization is termed as recruitment. It is the first step for selection and appointment of right employees for the organization. The organization publicises vacancies in the organization through newspaper advertisements, online job portals, consultancy services etc. Selection of candidates begins where their recruitment ends. In other words, it is only after an adequate number of applications have been secured through different sources of recruitment - internal or external that the process of selection begins (Chaturvedi, 2020). The recruitment and selection process is one of the most important aspects of running new and established businesses alike. The right employees can take your business to new heights. The wrong ones can hurt business by missing sales, turning customers off and creating a toxic workplace environment. The more effectively organizations recruit and select candidates, the more likely they are to hire and retain satisfied employees. In addition, the effectiveness of an organization's selection system can influence bottom-line business outcomes, such as productivity and financial performance (Ekwoaba, 2015).

\subsubsection{Profitability}

Profitability is ability of a company to use its resources to generate revenues in excess of its expenses. In other words, this is a company's capability of generating profits from its operations. Profitability is one of four building blocks for analyzing financial statements and company performance as a whole. The other three are efficiency, solvency, and market prospects. Investors, creditors, and managers use these key concepts to analyze how well a company is doing and the future potential it could have if operations were managed properly. profitability is a business's ability to produce a return on an investment based on its resources in comparison with an alternative investment (Horton, 2019). Firms often make the mistake of focusing just on revenues, operating under the assumption that greater revenue means greater profitability when, in fact, their profitability is the key metric. Profitability in an organization encourages business operation expansion, ability to borrow money from financial institutions, attracts investors financing, and gives room for hiring more employees (Johnson, 2019).

\subsubsection{Training and Development}

In the past few years, training and development have emerged as a crucial element of strategy. More company owners have realized that investing in employee training and development not only serves as a motivation, but it also enables the organization to create a highly skilled workforce. Employee training and development refers to the continued efforts of a company to boost the performance of its employees. Training and development describes the formal, ongoing efforts that are made within organizations to improve the performance and self-fulfillment of their employees through a variety of educational methods and programs (Ryan, 2018). Training is a systematic development of knowledge, skills and attitudes required by employees to perform adequately on a given taskor job. Training and 
development are required for staff to enable them work towards taking the organization to its expected destination.Training and development is one of the lowest things on the priority list of most companies. When it's organized, it is often at the persistence of the human resources department. There is, however, enormous value in organizing proper training and development sessions for employees. Training allows employees to acquire new skills, sharpen existing ones, perform better, increase productivity and be better leaders. Since a company is the sum total of what employees achieve individually, organization should do everything in their power to ensure that employees perform at their peak (Bhanu, 2015).

\subsubsection{Health and Safety}

Health and Safety Executive observed from the Labour Force Survey that in manufacturing over the past 5 years, each year an average of 22 workers died in workplace accidents. There was also an average of more than 3,100 reports of major injuries and about 4,100 reports of injuries that kept workers away from work for seven days or more. Many manufacturing workers also suffer ill health from workplace exposures. It is estimated that each year an average of 33,000 workers suffer from illness caused or made worse by their current or most recent job in manufacturing firms. Health and Safety procedures, guarantee the wellbeing of the workforce (Claire, 2018). Health and Safety surveys are crucial to establishing whether the workplace meets the required standards and if it is a safe place to be. It is very important to put the right safety processes in place to protect the entire team and manufacturing employees should be put through a mandatory induction course that predominantly focuses on Health and Safety. There should also be regular training opportunities, and, after a reasonable period, long-term employees should be made to recap the training and refresh it in their minds (Brown, 2018).

\subsubsection{Staff Retention}

Employee retention refers to the various policies and practices which let the employees stick to an organization for a longer period of time. Every organization invests time and money to groom the new workers, make them corporate ready material and bring them at par with the existing employees. The organization is completely at loss when the employees leave their job once they are fully trained. Employee retention takes into account the various measures taken so that an individual stays in an organization for the maximum period of time. Employee retention is a critical issue as companies compete for talent in a tight economy. The costs of employee turnover are increasingly high — as much as 2.5 times an employee's salary depending on the role. And there are other "soft costs": lowered productivity, decreased engagement, training costs and cultural impact (Sharon, 2019). to increase retention rate must start at the very beginning of the recruitment process, by recruiting the right people, identifying those that will stay, provision of ongoing education and clear paths to advancement, offering the right benefits, being transparent and open, provision of leverage technology, reduction of pain and making employee engagement possible (Chad, 2018).

\subsection{Theoretical Framework}

\section{Participative Decision Making Theory- RensisLikert, (1967)}

This theory focused on the extent by which employers allow or encourage employees to participate in organizational decision-making.Likert's ideas were based in the notion that supervisors with strong worker productivity tended to focus on the human aspects of subordinate problems while creating teams that emphasized high achievement. In other words, these supervisors were employee centered and believed that effective management required treating employees as humans and not just worker bees. Likert further noted that these highly productive leaders also tended to involve subordinates in the decision making 
process. In these organizations, organizational leaders have complete confidence in worker ability to make and implement decisions, so workers are constantly encouraged to be very active in the decision making process. Under participative management, communication, decision making participation, and teamwork is good, and employees tend to be motivated and satisfied. Involving subordinates in decisions may improve the quality and acceptance of decisions when participation fits the constraints of the situation. Human resource departments increasingly must act as a strategic partner with other organizations the company. recruiting, interviwing and hiring the right personnel to produce quality products and service depend on good communication between managers in all branches of the business (Tara, 2020).

\subsection{Empirical Review}

Ikwesi, (2010) conducted a study the effects of recruitment and selection procedures on the efficiency of the public service in Nigeria: A case study of Oshimili South local government of Delta state. The objective of the study was to provide deep-rooted information and data on the recruitment and selection of local government employee in the Oshimili south Local Government Council.The data used in this study was collected from both primary and secondary sources. The primary method or sources of data collection included the use of a research instrument, (the questionnaire) and interview. Some research questions were asked as guide to the respondents in order to elicit first hand information on the subject matter. The study found that recruitment and selection procedures in public service in Nigeria are not strictly followed during employment of staff; politicization and other informal processes dominate the established recruitment and selection procedures during employment of staff. The study concludes that there is an established relationship between inefficiency of the Nigerian public service and weak recruitment and selection processes. The study recommended that more strict measures should be introduced to ensure meritocracy in staff recruitment andnselection in the public service in Nigeria.

Kiiru, (2015) conducted a study on strategic human resource management practices and performance of parastatals in Kenya. The objective of the study was to examine the extent to which strategic human resource management practices influence performance of parastatals in Kenya. The philosophical foundation of the study was positivism. The study utilized both the descriptiveresearch design and explanatory research design which was cross-sectional survey in nature. The study population comprised of all the 185 parastatals in Kenya as outlined in the report of the presidential taskforce on parastatal reforms of 2013. Selfadministered questionnaires were used to collect primary data. Descriptive statistics were computed to describe the characteristics of the variables in the study while multiple regression analysis was used to establish the nature and magnitude of the relationships between the independent and dependent variables. The findings indicate that there is a significant positive relationship between training andparastatals ${ }^{\text {ee }}$ performance in Kenya, performance management has a significant positive relationship with performance of parastatals whilecompensation has a significant positive relationship with Parastatalsperformance in Kenya. The study concluded that human resource capabilities have a partial mediating effect on the relationship between stratic human resource management practices and organizational performance. The recommendations are; human resource managers should offer a variety of trainings to their staff, policy makers should create an adequate performance management framework that will effectively link performance of parastatals to national development goals and hence adequately link individual performance to institutional performance. 
Salah, (2016) conducted a study on impact of training and development on employees' performance and productivity "A case study of Jordanian Private Sector transportation companies located in the Southern region of Jordan. The purpose of the study was to investigate the relationship between training, development, training and development and employees' performance and productivity in selected Jordanian Private Sector transportation companies located in the Southern region of Jordan. A quantitative approach is used. Relevant data was collected through structured questionnaire. Subjects for the study consisted of 254 employees which constituted $60 \%$ of the total target population of 420 people. 254 structured questionnaires were distributed to employees on job location, 212 questionnaires were returned and only 188 were suitable for statistical analysis. SPSS version 16 has been used to for data analysis. Both descriptive and inferential statistics were used for data analysis. The statistical tools were aligned with the objective of the research. For this purpose, frequency tables, percentages, means and standard deviations were computed and substantively interpreted. Inferential statistics like Pearson product moment correlation coefficient (r) and linear regression were used to determine if there is a significant positive relationship existed between the independent variables (training and development) and dependent variables (performance and productivity). The findings indicated that training and development were positively correlated and claimed statistically significant relationship with employee performance and productivity. Analysis and interpretations were made at 0.05 level of significance. The study concluded that training and development have important impact on employee performance and productivity. Therefore, it was recommended that effective training programs and carefully set development plans should be provided to all employees to enable them to enhance their skills and upgrade their knowledge.

Nabi, Ahmed and Rahman, (2017), conducted research on the empirical study on human resource management practices with special reference to job satisfaction and employee turnover at investment corporation of Bangladesh. The objective of the study was to examine the relationship between Human resource management with the job satisfaction, Motivation, Training and Development, Absenteeism and turnover, Team work and employee's participation and compensation. The study is an exploratory research seeks to examine and analyze the impact of human resource management practices on job satisfaction of specialized public sector banking employees. The sample units include executives, middle level managers and managers of ICB Investment Bank. For the study 40 respondents were contacted for obtaining the information regarding HRM practices. But due to busy time schedules of bank employee and their engagement in various activities the numbers of respondents were restricted up to 30 . For obtaining the required information interview method is used and structured schedule is filled by the researcher. The study found that empowerment and recognition have positive effect on employee motivation. When empowerment and recognition of employees in an organization is increased, more will their motivation to work will enhance. The study concluded that when employees are satisfied with their basic needs then the employees will be satisfied more and the productivity will be higher and ultimate goal will be achieved and organizational discipline will be maintained. The recommended that would certainly help researchers, academicians, institutional and organizational practitioners and outcomes that would provide hints for future research in HR role and HR functions in the field of Research study.

Biswas\&Aditya, (2017), conducted research on strategic human resource management and employee performance: A study of selected Indian power sector PSUs. The objective of the study was to measure the effect of SHRM practices on employee performance in power sector PSUs.Convenient sampling procedure was adopted for the study and four power sector PSUs viz. Tehri Hydro Development Corporation, SatlujJalVidyut Nigam, National Hydro 
Power Corporation, and Power Grid Corporation Limited were identified for carrying out survey. Out of which 445 Questionnaires were returned out of which few were incomplete, total of 408 responses were found complete in all senses and suitable to be analyzed. The study is based on a sample size of 408 respondents working at different levels in the selected power sector PSUs. The study found that there is a significant relationship of SHRM practices and employees' performance. Based on findings the study concluded that employee performance is significantly influenced by factors related to Career Development, Employee Relation, Compensation, Performance Appraisal, Training Programmes, Working Climate, and Organizational \& Job Engagement. Therefore recommended that If HR practices can impact business success through building up organizational capabilities, improving employee satisfaction and commitment, New HR measures should be developed to drive business performance.

\subsection{Methodology}

The study based on the Human resources management strategy and performance of National Independent Power Projects. A study of Enugu distribution Comapany, South East, Nigeria comprising of Abia, Ebonyi, Enugu, Anambra and Imo states. The total staff population for the study was eight thousand, five hundred and fifty six $(8,556)$. They study covered period of (2008-2020). The study used the survey approach. The administration of questionnaire was done to the management and staff of the Enugu distribution Company Out of a population of 8.556 staff, the sample size of 364 was chosen after applying the Freund and William's formula for the determination of adequate sample size. 336 staff returned the questionnaire and accurately filled. That gave 92 percent response rate. The validity of the instrument was tested using content analysis and the result was good. The reliability was tested using the Pearson correlation coefficient (r). It gave a reliability co-efficient of 0.83 which was also good. Data was presented and analyzed by mean score (3.0 and above agreed while below 3.0 disagreed) and standard deviation using Sprint Likert Scale. The hypotheses were analyzed using Pearson correlation coefficient (r) statistic tool.

Research question one. What is the relationship between training and development on the profitability of National Independent Power Project?

Table 4.1: Responses to research question one: on the relationship between training and development on the profitability of National Independent Power Project

\begin{tabular}{|c|c|c|c|c|c|c|c|c|c|c|}
\hline & & $\begin{array}{l}5 \\
\text { VG } \\
\text { E }\end{array}$ & $\begin{array}{l}4 \\
\text { GE }\end{array}$ & $\begin{array}{l}3 \\
\text { NE }\end{array}$ & $\begin{array}{l}2 \\
\text { LE }\end{array}$ & $\begin{array}{l}\mathbf{1} \\
\text { VL } \\
\text { E }\end{array}$ & $\sum \mathbf{F X}$ & - & SD & $\begin{array}{l}\text { Decisio } \\
\text { n }\end{array}$ \\
\hline 1 & The learning in the National & 100 & 740 & 132 & 116 & 29 & 1117 & \multirow[t]{4}{*}{3.32} & 1.09 & \multirow[t]{4}{*}{ Agree } \\
\hline & Independent Power projects & 20 & 185 & 44 & 58 & 29 & 336 & & 8 & \\
\hline & has increased the income in & 6.0 & 55. & 13. & 17. & 8.6 & $100 \%$ & & & \\
\hline & the organisation. & & 1 & 1 & 3 & & & & & \\
\hline \multirow[t]{3}{*}{2} & The skilled staff have & 700 & 440 & 87 & 72 & 21 & 1320 & \multirow[t]{3}{*}{3.93} & 1.22 & \multirow[t]{3}{*}{ Agree } \\
\hline & improved the earnings in the & 140 & 110 & 29 & 36 & 21 & 336 & & 2 & \\
\hline & organisation. & 41.7 & $\begin{array}{l}32 . \\
7\end{array}$ & 8.6 & $\begin{array}{l}10 . \\
7\end{array}$ & 6.3 & $100 \%$ & & & \\
\hline \multirow[t]{4}{*}{3} & The knowledge in the & 520 & 372 & 468 & 62 & 59 & 1481 & \multirow[t]{4}{*}{3.45} & 1.45 & \multirow[t]{4}{*}{ Agree } \\
\hline & National Independent Power & 104 & 93 & 49 & 31 & 59 & 336 & & 3 & \\
\hline & projects have increased gross & 31.0 & 27. & 14. & 9.2 & 17. & $100 \%$ & & & \\
\hline & profit in the organisation. & & 7 & 6 & & 6 & & & & \\
\hline \multirow[t]{2}{*}{4} & The mental fitness has & 770 & 184 & 147 & 126 & 24 & 1251 & \multirow[t]{2}{*}{3.72} & 1.38 & \multirow[t]{2}{*}{ Agree } \\
\hline & reduced expenses in the & 154 & 46 & 49 & 63 & 24 & 336 & & 8 & \\
\hline
\end{tabular}


$\begin{array}{lllllll}\text { National independent Power } & 45.8 & 13 . & 14 . & 18 . & 7.1 & 100 \%\end{array}$

projects.

5 The increase in regeneration of National Independent

$\begin{array}{llll}575 & 696 & 96 & 2\end{array}$

$14 \quad 1383$

$4.12 \quad .902$

Agree

Power Projects has improved

115

$\begin{array}{lll}174 & 32 & 1\end{array}$

$14 \quad 336$

the net profits of the

$\begin{array}{llll}34.2 & 51 . & 9.5 & .3\end{array}$

$4.2 \quad 100 \%$

organisation.

$\begin{array}{llll}\text { Total grand mean and } & 3.70 & 1.21 \\ \text { standard deviation } & & 8 & 3\end{array}$

Source: Field Survey, 2020

From the table, it was agreed that learning in the National Independent Power projects has increased the income in the organization with mean score of 3.32and standard deviation of 1.098. The skilled staff has improved the earnings in the organisation with mean score of 3.93and standard deviation of 1.222. The knowledge in the National Independent Power projects have increased gross profit in the organisation with mean score of 3.45and standard deviation of 1.453. The mental fitness has reduced expenses in the National independent Power projects with mean score of 3.72and standard deviation of 1.388. The increase in regeneration of National Independent Power Projects has improved the net profits of the organisationwith a mean score of 4.12and standard deviation of .902.

Research Question Two. What is the relationship between recruitment and selection on the input of National Independent Power Project?

Table 4.1: Responses to research question two: on the relationship between recruitment and selection on the input of National Independent Power Project.

\begin{tabular}{|c|c|c|c|c|c|c|c|c|c|c|}
\hline & & $\begin{array}{l}5 \\
\text { VG } \\
\text { E }\end{array}$ & $\begin{array}{l}4 \\
\text { GE }\end{array}$ & $\begin{array}{l}3 \\
\text { NE }\end{array}$ & $\begin{array}{l}2 \\
\mathrm{LE}\end{array}$ & $\begin{array}{l}1 \\
\text { VLE }\end{array}$ & $\sum \mathbf{F X}$ & $\overline{\mathbf{X}}$ & SD & $\begin{array}{l}\text { Decisio } \\
\text { n }\end{array}$ \\
\hline \multirow[t]{3}{*}{1} & There is standard process & 955 & 404 & 45 & 24 & 17 & 1445 & 4.30 & 1.06 & Agree \\
\hline & used by managers in & 191 & 101 & 15 & 12 & 17 & 336 & & 0 & \\
\hline & $\begin{array}{l}\text { recruiting which } \\
\text { contribution quality } \\
\text { services }\end{array}$ & 56.8 & 30.1 & 4.5 & 3.6 & 5.1 & $100 \%$ & & & \\
\hline \multirow[t]{3}{*}{2} & The relevant and & 645 & 400 & 135 & 36 & 44 & 1260 & 3.75 & 1.36 & Agree \\
\hline & necessary people are & 129 & 100 & 45 & 18 & 44 & 336 & & 2 & \\
\hline & $\begin{array}{l}\text { involved in the } \\
\text { recruitment process which } \\
\text { helps in getting the right } \\
\text { people. }\end{array}$ & 38.4 & 29.8 & $\begin{array}{l}13 . \\
4\end{array}$ & 5.4 & 13.1 & $100 \%$ & & & \\
\hline \multirow[t]{3}{*}{3} & There is screening of & 775 & 440 & 90 & 58 & 12 & 1375 & 4.09 & 1.10 & Agree \\
\hline & candidates based on actual & 155 & 110 & 30 & 29 & 12 & 336 & & 1 & \\
\hline & position. & 46.1 & 32.7 & 8.9 & 8.6 & 3.6 & $100 \%$ & & & \\
\hline \multirow[t]{3}{*}{4} & On the basis of exposure & 785 & 460 & 93 & 34 & 16 & 1388 & 4.13 & 1.08 & Agree \\
\hline & and ability are needed. & 157 & 115 & 31 & 17 & 16 & 336 & & 5 & \\
\hline & & 46.7 & 34.2 & 9.2 & 5.1 & 4.8 & $100 \%$ & & & \\
\hline \multirow[t]{2}{*}{5} & There is prearranged & 835 & 464 & 75 & 24 & 16 & 1414 & 4.21 & 1.05 & Agree \\
\hline & strategy for hiring & 167 & 116 & 25 & 12 & 16 & 336 & & 0 & \\
\hline
\end{tabular}




\begin{tabular}{lllllllll}
\hline \hline employees & 49.7 & 34.5 & 7.4 & 3.6 & 4.8 & $100 \%$ & \\
\hline Total grand mean and & & & & & & $\mathbf{4 . 0 9}$ & $\mathbf{1 . 1 3}$ \\
standard deviation & & & & & $\mathbf{6}$ & $\mathbf{2}$ \\
\hline
\end{tabular}

Source: Field Survey, 2020

From the table, it was agreed that there is standard process used by managers in recruiting which contribution quality services with mean score of 4.30and standard deviation of 1.060. The relevant and necessary people are involved in the recruitment process which helps in getting the right people with mean score of 3.75and standard deviation of 1.362 . There is screening of candidates based on actual position with mean score of 4.09and standard deviation of 1.101. On the basis of exposure and ability are needed with mean score of 4.13and standard deviation of 1.085. There is prearranged strategy for hiring employees with a mean score of 4.21 and standard deviation of 1.050 .

Research Question Three. What is the relationship between health and safety on the staff retention of National Independent Power Project?

Table 4.1: Responses to research question three: on therelationship between health and safety on the staff retention of National Independent Power Project?

\begin{tabular}{|c|c|c|c|c|c|c|c|c|c|c|}
\hline & & $\begin{array}{l}5 \\
\text { VG } \\
\mathbf{E}\end{array}$ & $\begin{array}{l}\mathbf{G} \\
\text { GE }\end{array}$ & $\begin{array}{l}3 \\
\mathrm{NE}\end{array}$ & $\begin{array}{l}2 \\
\mathbf{L E}\end{array}$ & $\begin{array}{l}1 \\
\text { VLE }\end{array}$ & $\sum \mathbf{F X}$ & $\overline{\mathrm{X}}$ & SD & Decision \\
\hline 1 & $\begin{array}{l}\text { There is a safety plan to } \\
\text { make sure that salary and } \\
\text { benefits must be } \\
\text { competitive compare to } \\
\text { others. }\end{array}$ & $\begin{array}{l}935 \\
187 \\
55.7\end{array}$ & $\begin{array}{l}472 \\
118 \\
35 \\
1\end{array}$ & $\begin{array}{l}36 \\
12 \\
3.6\end{array}$ & $\begin{array}{l}22 \\
11 \\
3.3\end{array}$ & $\begin{array}{l}8 \\
8 \\
2.4\end{array}$ & $\begin{array}{l}1473 \\
336 \\
100 \%\end{array}$ & 4.38 & .890 & Agree \\
\hline 2 & $\begin{array}{l}\text { Effective policies must be } \\
\text { maintained for work life } \\
\text { balance. }\end{array}$ & $\begin{array}{l}785 \\
157 \\
46.7\end{array}$ & $\begin{array}{l}508 \\
127 \\
37 . \\
8\end{array}$ & $\begin{array}{l}51 \\
17 \\
5.1\end{array}$ & $\begin{array}{l}34 \\
17 \\
5.1\end{array}$ & $\begin{array}{l}18 \\
18 \\
5.4\end{array}$ & $\begin{array}{l}1396 \\
336 \\
100 \%\end{array}$ & 4.15 & $\begin{array}{l}1.08 \\
7\end{array}$ & Agree \\
\hline 3 & $\begin{array}{l}\text { There is training and } \\
\text { inductions to empower } \\
\text { personal development }\end{array}$ & $\begin{array}{l}645 \\
129 \\
38.4\end{array}$ & $\begin{array}{l}584 \\
146 \\
43 \\
5\end{array}$ & $\begin{array}{l}57 \\
19 \\
5.7\end{array}$ & $\begin{array}{l}44 \\
22 \\
6.5\end{array}$ & $\begin{array}{l}20 \\
20 \\
6.0\end{array}$ & $\begin{array}{l}1350 \\
336 \\
100 \%\end{array}$ & 4.02 & $\begin{array}{l}1.11 \\
4\end{array}$ & Agree \\
\hline 4 & $\begin{array}{l}\text { There is monitoring to help } \\
\text { successful work schedule } \\
\text { flexibility. }\end{array}$ & $\begin{array}{l}135 \\
27 \\
8.0\end{array}$ & $\begin{array}{l}868 \\
217 \\
64 . \\
6\end{array}$ & $\begin{array}{l}87 \\
29 \\
8.6\end{array}$ & $\begin{array}{l}76 \\
38 \\
11.3\end{array}$ & $\begin{array}{l}25 \\
25 \\
7.4\end{array}$ & $\begin{array}{l}1191 \\
336 \\
100 \%\end{array}$ & 3.54 & $\begin{array}{l}1.04 \\
1\end{array}$ & Agree \\
\hline 5 & $\begin{array}{l}\text { Effective reporting gives } \\
\text { rise to recognition and } \\
\text { reward in National } \\
\text { Independent power } \\
\text { projects }\end{array}$ & $\begin{array}{l}695 \\
139 \\
41.4\end{array}$ & $\begin{array}{l}420 \\
105 \\
31 . \\
3\end{array}$ & $\begin{array}{l}117 \\
39 \\
11 . \\
6\end{array}$ & $\begin{array}{l}36 \\
18 \\
5.4\end{array}$ & $\begin{array}{l}34 \\
34 \\
10.1\end{array}$ & $\begin{array}{l}1302 \\
336 \\
100 \%\end{array}$ & 3.89 & $\begin{array}{l}1.28 \\
5\end{array}$ & Agree \\
\hline & $\begin{array}{l}\text { Total grand mean and } \\
\text { standard deviation }\end{array}$ & & & & & & & $\begin{array}{l}3.99 \\
6\end{array}$ & $\begin{array}{l}1.08 \\
3\end{array}$ & \\
\hline
\end{tabular}

Source: Field Survey, 2020

From the table, it was agreed that there is a safety plan to make sure that salary and benefits must be competitive compare to others with mean score of 4.38and standard deviation of 
.890. Effective policies must be maintained for work life balance with mean score of 4.15 and standard deviation of 1.087. There is training and inductions to empower personal development with mean score of 4.02and standard deviation of 1.114. There is monitoring to help successful work schedule flexibility with mean score of 3.54and standard deviation of 1.041. Effective reporting gives rise to recognition and reward in National Independent power projects with a mean score of 3.89and standard deviation of 1.285.

\subsection{Test of Hypotheses}

4.2.1 Hypothesis One: There is a relationship between training and development on the profitability of National Independent Power Project.

Table 4.2.1.1: Pearson Correlation onthe relationship between training and development on the profitability of National Independent Power Project.

\begin{tabular}{|c|c|c|c|c|}
\hline Pearson & $\begin{array}{l}\text { The relationship } \\
\text { between training } \\
\text { development on } \\
\text { the profitability }\end{array}$ & $\begin{array}{l}\text { Correlation } \\
\text { coefficient Sig. } \\
\text { (2-tailed) } \\
\text { N } \\
\\
\text { Correlation } \\
\text { Coefficient } \\
\text { Sig. (2 tailed) } \\
\text { N }\end{array}$ & $\begin{array}{l}\text { The } \\
\text { relationship } \\
\text { between } \\
\text { training } \\
1 \\
336 \\
.708(* *) \\
000 \\
336\end{array}$ & $\begin{array}{l}\text { development on the } \\
\text { profitability } \\
.708(* *) \\
000 \\
336 \\
1 \\
336\end{array}$ \\
\hline
\end{tabular}

** correlation is significant at the 0.05 level ( 2 tailed)

Table 4.2.1.1 is the Pearson correlation matrix onthe relationship between training and development on the profitability of National Independent Power Project showing the correlation coefficients, significant values and the number of cases. The correlation coefficient shows 0.708 . This value indicates that correlation is significant at 0.05 level (2 tailed) and implies that there was a relationship between training and development on the profitability of National Independent Power Project ( $\mathrm{r}=.708)$. The computed correlations coefficient is greater than the table value of $r=.195$ with 879 degree of freedom $(\mathrm{df} .=\mathrm{n}-2)$ at alpha level for a two-tailed test $(\mathrm{r}=.71, \mathrm{p}<.05)$.

\section{Decision Rule}

The decision rule is to accept the null hypothesis if the computed $r$ is less than the tabulated $r$ otherwise reject the null hypothesis. 


\section{Decision}

Since the computed $\mathrm{r}=0.708$ is greater than the table value of .195 , we reject the null hypothesis. Therefore, we conclude that there was a relationship between training and development on the profitability of National Independent Power Project as reported in the probability value of $(\mathrm{r}=.71, \mathrm{p}<.05)$.

4.2.2 Hypothesis Two: Recruitment and selection has relationship with the input in National Independent Power Project

Table 4.2.2.1: Pearson Correlation on Recruitment and selection has relationship with the

input in National Independent Power Project

\begin{tabular}{|c|c|c|c|c|}
\hline Pearson & $\begin{array}{l}\text { Recruitment } \\
\text { selection has } \\
\text { relationship with } \\
\text { the } \\
\text { input }\end{array}$ & $\begin{array}{l}\text { Correlation } \\
\text { coefficient Sig. } \\
\text { (2-tailed) } \\
\mathrm{N} \\
\\
\text { Correlation } \\
\text { Coefficient } \\
\text { Sig. (2 tailed) } \\
\mathrm{N}\end{array}$ & $\begin{array}{l}\text { Recruitment } \\
1 \\
\\
336 \\
.669(* *) \\
000 \\
336\end{array}$ & $\begin{array}{l}\text { selection has } \\
\text { relationship with the } \\
\text { input } \\
.669(* *) \\
000 \\
336 \\
1 \\
336\end{array}$ \\
\hline
\end{tabular}

** Correlation is significant at the 0.05 level (2 tailed)

Table 4.2.2.1 is the Pearson correlation matrix on recruitment and selection has relationship with the input in National Independent Power Projectshowing the correlation coefficients, significant values and the number of cases. The correlation coefficient shows 0.669 . This value indicates that correlation is significant at 0.05 level (2 tailed) and implies that recruitment and selection hada relationship with the input in National Independent Power Project $(\mathrm{r}=.669)$. The computed correlations coefficient is greater than the table value of $\mathrm{r}=$ .195 with 879 degree of freedom $(\mathrm{df} .=\mathrm{n}-2)$ at alpha level for a two-tailed test $(\mathrm{r}=.67$, $\mathrm{p}<.05)$.

\section{Decision Rule}

The decision rule is to accept the null hypothesis if the computed $r$ is less than the tabulated $r$ otherwise reject the null hypothesis. 


\section{Decision}

Since the computed $r=0.669$ is greater than the table value of .195 , we reject the null hypothesis. Therefore, we conclude that recruitment and selection hada relationship with the input in National Independent Power Projectas reported in the probability value of $(r=.67$, $\mathrm{p}<.05)$.

4.2.3 Hypothesis Three:There is a relationship between health and safety on the staff retention of National Independent Power Project

Table 4.2.3.1: Pearson Correlation on There is a relationship between health and safety on

thestaff retention of National Independent Power Project

\begin{tabular}{|c|c|c|c|c|}
\hline Pearson & $\begin{array}{l}\text { The relationship } \\
\text { between health } \\
\text { safety on } \\
\text { the staff } \\
\text { retention }\end{array}$ & $\begin{array}{l}\text { Correlation } \\
\text { coefficient Sig. } \\
\text { (2-tailed) } \\
\mathrm{N} \\
\\
\text { Correlation } \\
\text { Coefficient } \\
\text { Sig. (2 tailed) } \\
\mathrm{N}\end{array}$ & $\begin{array}{l}\text { The } \\
\text { relationship } \\
\text { between } \\
\text { health } \\
1 \\
336 \\
.665(* *) \\
000 \\
336\end{array}$ & $\begin{array}{l}\text { safety onthe staff } \\
\text { retention } \\
.665(* *) \\
000 \\
336 \\
1 \\
336\end{array}$ \\
\hline
\end{tabular}

** correlation is significant at the 0.05 level ( 2 tailed)

Table 4.2.3.1 is the Pearson correlation matrix on the relationship between health and safety on the staffretention of National Independent Power Project showing the correlation coefficients, significant values and the number of cases. The correlation coefficient shows 0.665. This value indicates that correlation is significant at 0.05 level ( 2 tailed) and implies that there was a relationship between health and safety on the staff retention of National Independent Power Project ( $\mathrm{r}=.665)$. The computed correlations coefficient is greater than the table value of $\mathrm{r}=.195$ with 879 degree of freedom $(\mathrm{df} .=\mathrm{n}-2)$ at alpha level for a two-tailed test $(\mathrm{r}=.67, \mathrm{p}<.05)$.

\section{Decision Rule}

The decision rule is to accept the null hypothesis if the computed $r$ is less than the tabulated $r$ otherwise reject the null hypothesis.

\section{Decision}

Since the computed $r=0.665$ is greater than the table value of .195 , we reject the null hypothesis. Therefore, we conclude that there was a relationship between health and safety on the staff retention of National Independent Power Project as reported in the probability value of $(r=.67, p<.05)$. 


\subsection{Discussion of Findings}

From the result hypothesis one, the computed $r=0.708$ is greater than the table value of .195 , we reject the null hypothesis. Thus the alternative hypothesis was accepted which states that there was a relationship between training and development on the profitability of National Independent Power Project. In support of result above, Training and development describes the formal, ongoing efforts that are made within organizations to improve the performance and self-fulfillment of their employees through a variety of educational methods and programs. Salah, (2016) concluded that training and development have important impact on employee performance and productivity. From the result hypothesis two, the computed $\mathrm{r}=$ 0.669 is greater than the table value of .195 , we reject the null hypothesis. Thus the alternative hypothesis was accepted which states that recruitment and selection had a relationship with the input in National Independent Power Project. In support of the result, Recruitment and selection is one of the important aspects of human resource planning. Human resource planning ensures that right kind and right quality of employees are employed so as to achieve the organizational goals. Ikwesi, (2010) found that recruitment and selection procedures in public service in Nigeria are not strictly followed during employment of staff. From the result hypothesis three, the computed $r=0.665$ is greater than the table value of .195, we reject the null hypothesis. Thus the alternative hypothesis was accepted which states thatthere was a relationship between health and safety on the staff retention of National Independent Power Project. In support of the result, Health and Safety surveys are crucial to establishing whether the workplace meets the required standards and if it is a safe place to be. Claire, (2018), states that Health and Safety procedures guarantee the wellbeing of the workforce.

\section{Conclusion.}

The study concluded that there is a relationship between training and development, recruitment and selection, health and safety on the profitability, input and staff retention of National Independent Power Project. Human resource management strategy is a designation for a long-term plan created to achieve objectives in the field of human resource and human capital management and development in the organization, its sets the direction for all the key areas of human resource including hiring, performance appraisal, development and compensation. There is enormous value in organizing proper training and development sessions for employees. Training allows employees to acquire new skills, sharpen existing ones, perform better, increase productivity and be better leaders. It is very important to put the right safety processes in place to protect the entire team.

\section{Recommendation}

Based on the findings of the study, the following recommendations were made:

i. Manufacturing employees should be put through mandatory induction courses that predominantly focus on health and safety in National Independent Power project.

ii. Training and development of employees should be conducted periodical in National Independent Power Project to enhance employees' performance and productivity.

iii. There is should be strict procedure in recruitment selection process in National Independent Power project.

\section{Reference}

1. Bhanu, C. (2015), Importance of training and development in an organization. Retrieved from https://economictimes.indiatimes.com/small-biz/hr-leadership/people/importanceof-training-and-development-in-an-organization/articleshow/48739569.cms?from $=m d r$ 
2. Biswas\&Aditya, (2017). Strategic human resource management and employee performance: A study of selected Indian power sector PSUs. KAAV International Journal of Economics, Commerce \& Business Management. 4. 21-29

3. Brown, T. (2018), Manufacturing \& the importance of health \& safety. Retrieved from https://www.themanufacturer.com/articles/manufacturing-importance-health-safety/

4. Canal, (2020), Human resource management. Retrieved from https://www.inc.com/encyclopedia/human-resource-management.html

5. Chad, H. (2018), 7 great employee retention strategies. Retrieved from https://wheniwork.com/blog/7-great-employee-retention-strategies/

6. Chaturvedi, S. (2020), Recruitment and selection process. Retrieved from http://www.economicsdiscussion.net/human-resource-management/recruitment-andselection-process $/ 31594$

7. Chirgwin, C (2016), The importance of Strategy. Retrieved from https://www.lanspeed.com/the-importance-of-strategy/

8. Claire, M. (2018), Manufacturing Health and Safety: The complete guide. Retrieved from https://www.wirehouse-es.com/2018/09/28/health-and-safety-in-manufacturing/

9. Ekwoaba, (2015), Recruitment and selection strategies on employees' performance. Retrieved from https://researchleap.com/impact-recruitment-selection-strategyemployees-performance-study-three-selected-manufacturing-companies-nigerial

10. Erik, (2019), How to create a human resource strategy. Retrieved from https://www.digitalhrtech.com/human-resource-strategy/

11. Heathfield, S. (2019), What is human resource management? Retrieved from https://www.thebalancecareers.com/what-is-human-resource-management-1918143

12. Horton, M. (2019), The difference between profitability and profit. Retrieved from https://www.investopedia.com/ask/answers/012715/what-difference-between-profitabilityand-profit.asp

13. Ikwesi, P. (2010), The effects of recruitment and selection procedures on the efficiency of the public service in Nigeria: A case study of Oshimili South local government of Delta state. retrieved from http://www.unn.edu.ng/publications/files/images/mpa\%20thesis\%20correction\%20versio n\%20philip.pdf

14. Johnson, R. (2019), What are the benefits of making a profit? Retrieved from https://smallbusiness.chron.com/benefits-making-profit-38877.html

15. Juneja, P. (2015), Strategy - definition and features. Retrieved from https://www.managementstudyguide.com/strategy-definition.htm

16. Kiiru, D. M. (2015), Strategic human resource management practices and performance of parastatals in Kenya. Retrieved from https://irlibrary.ku.ac.ke/bitstream/handle/123456789/14238/Strategic\%20human\%20resource\%2 Omanagement $\% 20$ practices $\% 20$ and $\% 20$ performance....pdf? sequence $=1 \&$ isAllowed $=y$

17. Louise, J. (2012), What is organisational performance? Retrieved from http://www.growth.pitcher.com.au/resources/articles/what-is-organisational-performance

18. Mitchell, L. (2020), The role of strategic human resource management. Retrieved from https://www.smartsheet.com/strategic-human-resource-management

19. Nabi, Ahmed and Rahman, (2017), The empirical study on human resource management practices with special reference to job satisfaction and employee turnover at investmen corporation of Bangladesh. Human Resource Management Research, 2017; 7(1): 54-64

20. Okedu, K. (2018), Impact of the Independent Power Producers and National Integrated Power Project on the Deregulation of the Nigerian Electricity Sector. Retrieved from https://www.researchgate.net/publication/327831926_Impact_of_the_Independent_Powe 
$r$ rProducers_and_National_Integrated_Power_Projects_on_the_Deregulation_of_the_N igerian_Electricity_Sector

21. Ryan, (2018), Training and development. Retrieved from https://www.inc.com/encyclopedia/training-and-development.html

22. Salah, M. (2016). The impact of training and development on employees performance and productivity "A case study of Jordanian Private Sector transportation companies located in the Southern region of Jordan. A particular reference is made to the Govern ate Maan". International Journal of Management Sciences and Business Research. 5, 36-70

23. Sawyer, K. (2019), 7 steps to strategic human resource management. Retrieved from https://www.deputy.com/blog/7-steps-to-strategic-human-resource-management

24. Seidel, (2019), What are Human resource strategies? Retrieved from https://smallbusiness.chron.com/hrm-strategies-59260.html

25. Sharon, F. (2019), Employee retention: 8 strategies for retaining top talent. Retrieved from https://www.cio.com/article/2868419/how-to-improve-employee-retention.html

26. Smyth, D. (2019), What are Human resource management strategies? Retrieved from https://bizfluent.com/about-5529235-hrm-strategies.html

27. Stuart, H. (2018), Why is performance management important? Retrieved from https://www.clearreview.com/why-performance-management-important/

28. Tara, D. (2020), About strategic Human Resource: Theory \& Principle. Retrieved from https://smallbusiness.chron.com/strategic-hr-theory-principles-17495.html 